\title{
Studi Deskriptif Implementasi Pembelajaran Daring melalui Learning Management System di Pusat Pengembangan Sumber Daya Manusia Minyak dan Gas Bumi
}

\author{
Mohammad Hasan Syukur
}

Pusat Pengembangan Sumber Daya Manusia Minyak dan Gas Bumi, Cepu

\author{
INFORMASI NASKAH \\ Diterima: 4 Maret 2021 \\ Direvisi: 6 April 2021 \\ Disetujui: 19 Juli 2021 \\ Terbit: 30 September 2021 \\ Email korespondensi: \\ muhammad.syukur@esdm.go.id
}

Laman daring:

https://doi.org/10.37525/

$\mathrm{sp} / 2021-2 / 284$

\begin{abstract}
ABSTRAK
Era pandemi covid-19 telah mengganggu proses pembelajaran secara konvensional. Maka diperlukan solusi untuk menjawab permasalahan tersebut. Pembelajaran secara daring adalah salah satu alternative yang dapat mengatasi masalah tersebut. Tujuan penelitian adalah untuk memperoleh gambaran pelaksanaan pembelajaran daring di PPSDM MIGAS. Metodologi Penelitian yang dilakukan adalah dengan survey melalui angket dengan google form yang disebar kepada stake holder penyelengara pelatihan dan pengajar (Widyaiswara dan instruktur).

Dari hasil penelitian diperoleh data bahwa 97,6\% menyatakan PPSDM MIGAS melaskanakan pembelajaran daring, 95,1\% menyatakan pembelajaran dari adalah kombinasi Video conference dan LMS, 82,9\% mampu menyelenggarakan pembelajaran daring, 95,1\% lebih senang dengan zoom daripada platform lainnya, 80,5\% lebih senang Whatsapp grup sebagai asinkron dalam pembelajaran online, 22\% menerima bandwith di bawah 10 Mbps.Secara keseluruhan hasil ini menyatakan bahwa Stakeholder PPSDM MIGAS siap melaksanakan pembelajaran daring akan tetapi masih diperlukan pengembangan SDM baik dalam pengelolaan LMS dan dalam membuat bahan bahan tayang dan media pembelajaran dalan bentuk video, simulasi dan sebagainya.
\end{abstract}

Kata kunci: Pembelajaran Daring. Learning Management System 


\section{PENDAHULUAN}

Era pandemi covid-19 telah mengganggu proses pembelajaran secara konvensional. Maka diperlukan solusi untuk menjawab permasalahan tersebut. Pembelajaran secara daring adalah salah satu alternatif yang dapat mengatasi masalah tersebut. Proses pembelajaran merupakan kegiatan interaksi antara pengajar sebagai fasilitator di kelas dan peserta pelatihan di kelas. Dalam proses pembelajaran melibatkan kegiatan belajar dan mengajar yang dapat menentukan keberhasilan peserta pelatihan serta untuk mencapai tujuan pembelajaran. Belajar merupakan suatu perubahan perilaku yang terjadi pada individu, yang sebelumnya tidak bisa menjadi bisa atau mahir.

Wabah corona virus disease 2019 (Covid-19) bukan hanya di Indonesia, tetapi telah melanda 215 negara di dunia, memberikan tantangan tersendiri bagi institusi pemerintah khususnya PPSDM MIGAS. Untuk melawan Covid-19 Pemerintah telah melarang untuk berkerumun, pembatasan sosial (social distancing) dan menjaga jarak fisik (physical distancing), memakai masker dan selalu cuci tangan (ESDM, 2020) Surat Edaran Sekretariat Jenderal ESDM.Nomor 6 E/70/SJN.P/2020) Kementerian Energi dan Sumber Daya Mineral telah melarang instansi di bawahnya untuk melaksanakan pertemuan tatap muka (konvensional) dan memerintahkan untuk mengoptimalkan secara daring baik kegiatan rapat maupun penyelenggaraan pelatihan. PPSDM MIGAS dituntut untuk dapat menyelenggarakan pembelajaran secara daring atau on line. Di awal 2020 PPSDM MIGAS belum siap perangkat Learning management System (LMS) dengan Moodle, baru memanfaatkan google classroom sebagai Learning Management System, dengan seiring waktu berjalan Moodle dibangun dengan alamat http://elsa-ppsdmmigas. esdm.go.id sebagai Learning Management System. Dengan adanya LMS ini, tentunya perlu pengetahuan lebih untuk menggunakan system pembelajaran ini sebagai pendukung pembelajaran asynchronous. Tidak terjadi Gap karena pengajar tidak menguasai LMS yang tersedia. Sebagaimana pendapat Angelika Riyandari, dalam tulisannya Never Too Old to Learn : Dosen Gen-X Menjawab tantangan Daring di hal 122 -123 (Prof. Dr. F. Ridwan Sanjaya, MS.IEC , 2020) ada 4 Tantangan dalam Pembelajaran Daring.

Tujuan Penelitian adalah untuk untuk memetakan keberadaan dan implementasi pembelajaran daring pada Pusat Pengembangan Sumber Daya Manusia Minyak dan Gas Bumi (PPSDM MIGAS) serta untuk menggambarkan peta proses, infrastruktur pembelajaran daring dan aspek-aspek lainnya di instansi PPSDM MIGAS.

\section{TINJAUAN PUSTAKA}

Dalam proses pembelajaran melibatkan kegiatan belajar dan mengajar yang dapat menentukan keberhasilan siswa serta untuk mencapai tujuan pendidikan. Belajar merupakan suatu perubahan perilaku yang terjadi pada individu, yang sebelumnya tidak bisa menjadi bisa atau mahir. Bentuk perkuliahan yang dapat dijadikan solusi dalam masa pandemi covid-19 adalah pembelajaran daring. Pembelajaran daring merupakan pembelajaran yang menggunakan jaringan internet dengan aksesibilitas, konektivitas, fleksibilitas, dan kemampuan untuk memunculkan berbagai jenis interaksi pembelajaran. Adanya pandemic covid19 ini mampu merombak cara penyampaian pengetahuan dan dapat menjadi alternative pembelajaran yang dilaksanakan dalam kelas tradisional. Pada tataran pelaksanaanya pembelajaran daring memerlukan dukungan perangkat - perangkat mobile seperti smarphone atau telepon adroid, laptop, komputer, tablet, dan iphone yang dapat dipergunakan untuk mengakses informasi kapan saja dan dimana saja.. Pembelajaran daring dibutuhkan dalam pembelajaran di era revolusi industri 4.0 Berbagai 
media juga dapat digunakan untuk mendukung pelaksanaan pembelajaran secara daring. Misalnya kelas-kelas virtual menggunakan layanan Moodle, Google Classroom, Edmodo, dan Schoology dan aplikasi pesan instan seperti WhatsApp dan Telegram. Pembelajaran secara daring bahkan dapat dilakukan melalui media social seperti Telegram, Facebook dan Instagram. Waryanto (2006) mengungkapkan bahwa keuntungan dari model pembelajaran daring adalah dapat digunakan untuk menyampaikan pembelajaran tanpa dibatasi ruang dan waktu, dapat menggunakan berbagai sumber yang sudah tersedia di internet, dan bahan ajar relatif mudah

untuk diperbaharui. Selain itu, dapat meningkatkan kemandirian peserta didik dalam proses pembelajaran.

Pembelajaran daring menghubungkan peserta didik dengan sumber belajarnya (database, pakar/instruktur, perpustakaan) yang secara fisik terpisah atau bahkan berjauhan namun dapat saling berkomunikasi, berinteraksi atau berkolaborasi (secara langsung/synchronous dan secara tidak langsung/asynchronous). Pembelajaran daring adalah bentuk pembelajaran jarak jauh yang memanfaatkan teknologi telekomunikasi dan informasi, misalnya internet, CD-ROOM (Molinda, 2005). (Ali Sadikin, 2020).

Pembelajaran daring mengakibatkan kurangnya interaksi antara guru dan siswa bahkan antar-siswa itu sendiri. Kurangnya interaksi ini bisa memperlambat terbentuknya values dalam proses belajar mengajar.Pembelajaran daring yang dilaksanakan saat ini menjadi hal baru yang dirasakan oleh guru maupun peserta didik. Berdasarkan permasalahan yang telah diuraikan sebelumnya, maka peneliti terdorong untuk memberikan gambaran mengenai proses pembelajaran daring untuk guru pada masa pandemi COVID-19 serta memberikan gambaran mengenai faktor-faktor pendukung juga factor factor yang menjadi hambatan guru dalam proses pembelajaran daring pada masa pandemic COVID19. (Hilna Putria , 2020).

\section{METODE PENELITIAN}

Penelitian ini menggunakan metode penelitian kualitatif deskriptif. Adapun Teknik yang digunakan adalah teknik survey. Penelitian yang dilakukan adalah dengan survey melalui angket dengan google form yang disebar kepada stake holder penyelengara pelatihan dan pengajar (Widyaiswara dan instruktur). Yang selanjutnya data ini ditampilkan dalam studi deskripsi sajian bentuk infografis. Ada beberapa pertanyaan yang diberikan kepada 50 responden, mengapa diambil 50 karena total jumlah pengajar di PPSDM MIGAS 95 orang terdiri dari 18 WI dan 77 instruktur, sehingga minimal sampel adalah sebagai berikut: 49 orang berdasarkan persamaan ukuran Sampel

$$
n=\frac{N}{1+\left(N x \theta^{2}\right)}
$$

dimana

$\mathrm{n}=$ jumlah sampel

$\mathrm{N}=$ ukuran populasi pengajar

$\mathrm{e}=$ prosen kesalahan pengambilan sampel yang masih diinginkan (Novy Trisnani, 2019) 
dengan 10\% kesalahan, maka diperoleh 48,72 orang, dibulatkan menjadi 49 responden yang diberi pertanyaan survey sebagai berikut :

- Menurut anda, yang lebih baik dalam Bentuk pembelajaran daring yang diselenggarakan di PPSDM MIGAS

- Pengalaman PPSDM MIGAS dalam menyelenggarakan pembelajaran daring

- Berapa Persentase jumlah diklat yang diselenggarakan secara daring, sepengatahuan anda?

- Apakah anda sebagai pengajar mampu menyelenggarakan mata diklat daring

- Persentase tim admin penyelenggara yang mampu menyelenggarakan pembelajaran daring

- Cara Pengajar di PPSDM MIGAS mengembangkan objek ajar (bahan ajar elektronik dalam bentuk file teks/dokumen, audio, visual, audio-visual, animasi, games, simulasi dan sebagainya) untuk pembelajaran daring

- Ragam objek ajar apa saja yang digunakan dalam pembelajaran daring di PPSDM MIGAS

- Fasilitas penyelenggaraan pembelajaran daring yang saat ini digunakan oleh pengajar di PPSDM MIGAS

- Ragam aktivitas dan tool SINKRON yang digunakan dalam sistem pembelajaran daring di PPSDM MIGAS

- Ragam aktivitas dan tool ASINKRON yang digunakan dalam sistem pembelajaran daring di PPSDM MIGAS

- Aplikasi dan tool yang digunakan untuk pengembangan objek ajar pembelajaran daring di PPSDM MIGAS

- Besar bandwidth wifi yang diterima anda di lingkungan PPSDM MIGAS

- $\quad$ Sistem pendukung yang tersedia di PPSDM MIGAS

- SDM pendukung pembelajaran daring di PPSDM MIGAS

- Jumlah SDM yang terlibat dalam Instructional designer (Perancang Pembelajaran)

- Jumlah SDM yang terlibat pengembang media pembelajaran (perancang, pembuatan video pembelajaran dll):

- PPSDM MIGAS memiliki unit penanggung jawab mutu pembelajaran secara daring

- PPSDM MIGAS memberikan pelatihan bagi staf yang terlibat dalam program pembelajaran daring

- Peserta pelatihan dari pegawai PPSDM MIGAS yang sudah mengikuti Pembelajaran daring

- Materi pelatihan yang sudah diberikan oleh instansi Anda

- Seberapa jauh anda sudah bisa menggunakan power point?

- Seberapa jauh anda sudah bisa menggunakan software Interaktif Learning?

- Seberapa jauh anda sudah bisa menggunakan software video pembelajaran? 


\section{HASIL PENELITIAN DAN PEMBAHASAN}

Setelah dilakukan survey dengan menggunakan aplikasi google form, maka diperoleh data hasil penelitian sebagai berikut :

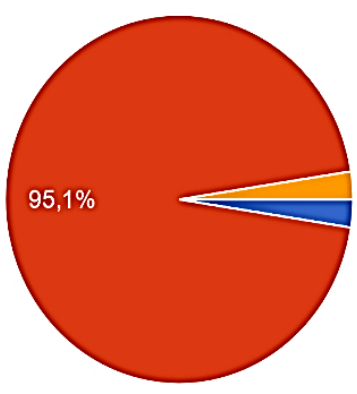

Full Video Conference Live Streaming ( memindahkan kelas tatap muka nyata ke tatap muka maya)

O Kombinasi Video Conference atau sebagian diselenggarakan secara daring/online dengan menggunakan Learning Management System

Lainnya:

Gambar 1 Bentuk pembelajaran daring yang diselenggarakan di PPSDM MIGAS

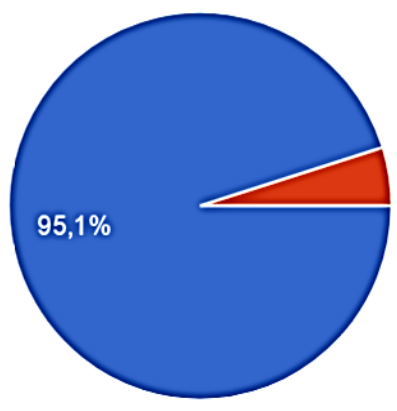

$0<5$ tahun
$0>5$ tahun

Gambar 2 Pengalaman PPSDM MIGAS dalam menyelenggarakan pembelajaran daring
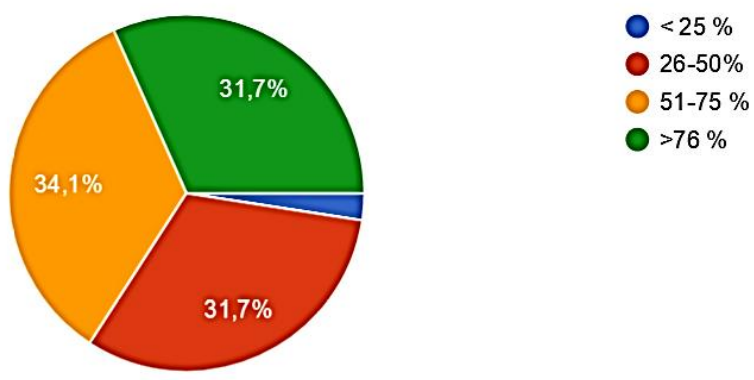

Gambar 3 Persentase jumlah diklat yang diselenggarakan secara daring (sumber : responden)

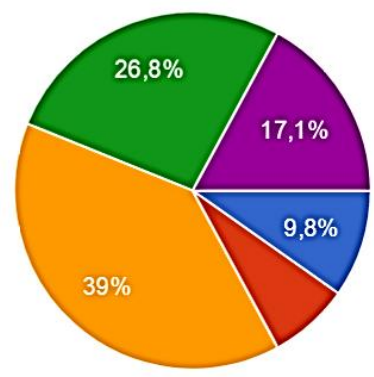

$\cdot>90 \% \mathrm{mampu}$ 
Gambar 4 pengajar mampu menyelenggarakan mata diklat daring

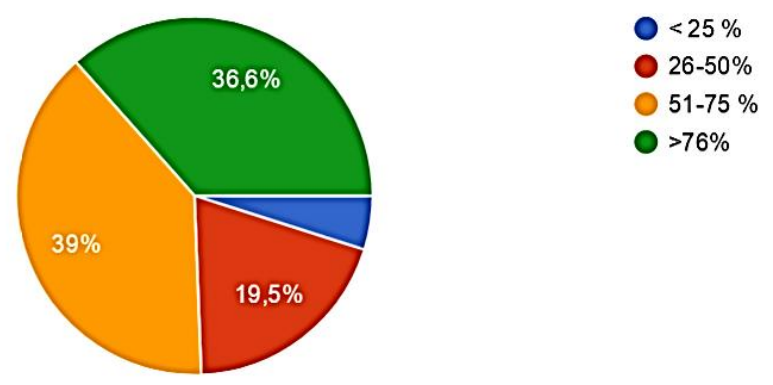

Gambar 5 Persentase tim admin penyelenggara yang mampu menyelenggarakan pembelajaran daring

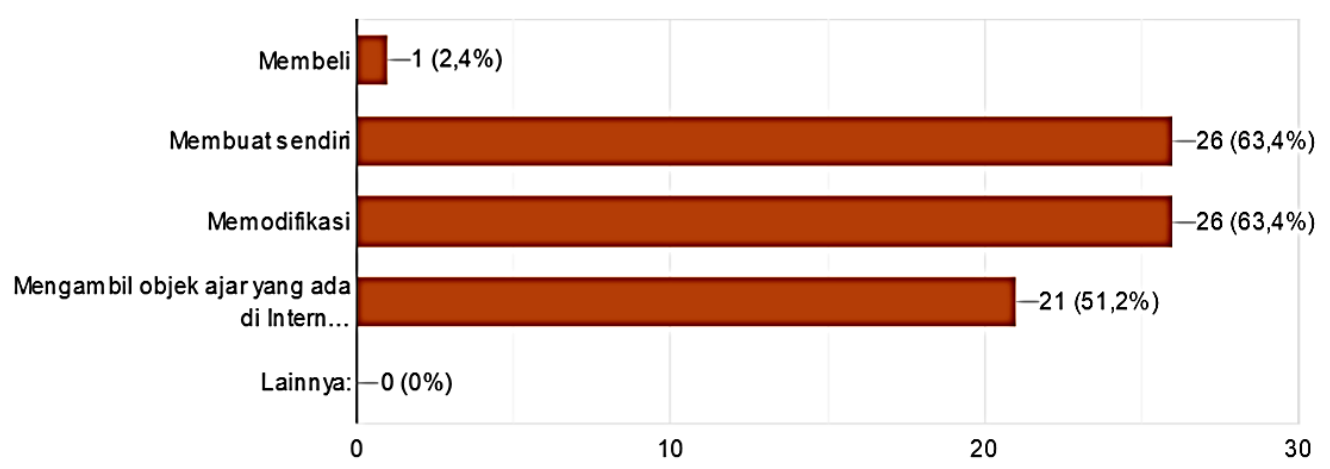

Gambar 6 Cara Pengajar di PPSDM MIGAS mengembangkan objek ajar (bahan ajar elektronik dalam bentuk file teks/dokumen, audio, visual, audio-visual, animasi, games, simulasi dan sebagainya) untuk pembelajaran daring

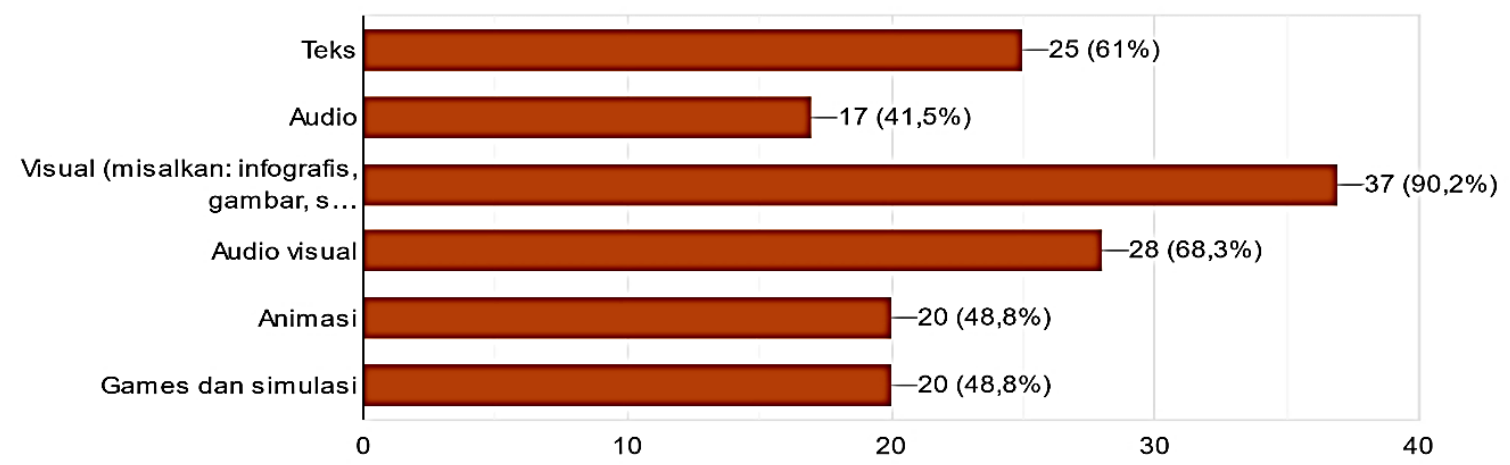

Gambar 7 Ragam objek ajar apa saja yang digunakan dalam pembelajaran daring di PPSDM MIGAS 


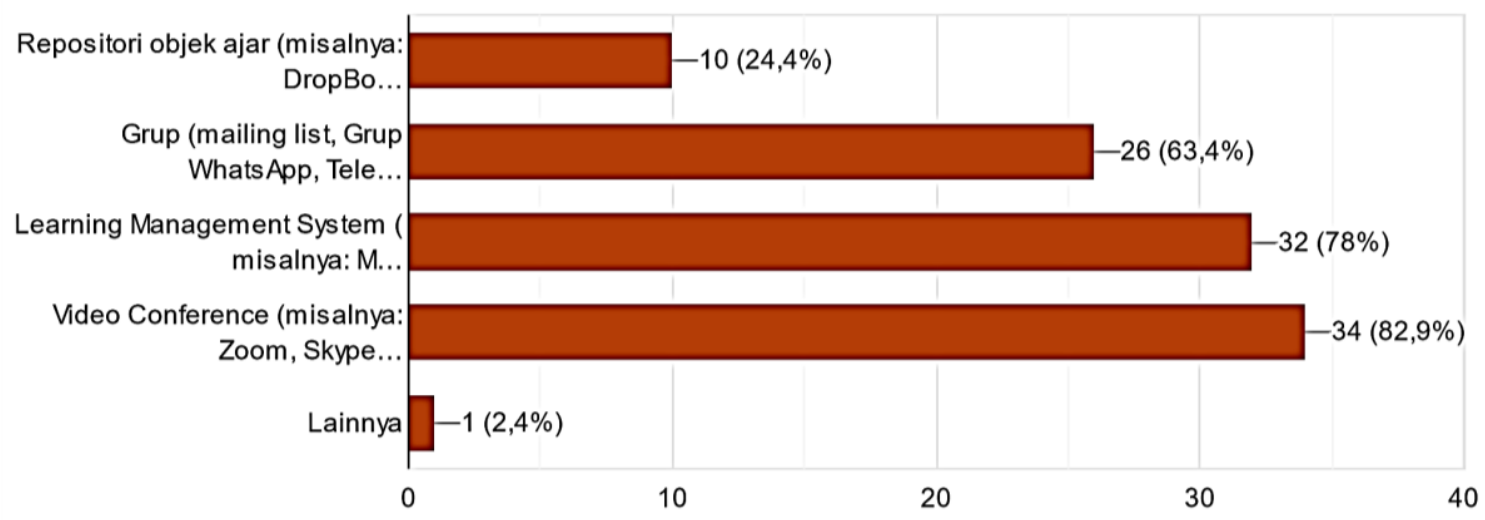

Gambar 8 Fasilitas penyelenggaraan pembelajaran daring yang saat ini digunakan oleh pengajar di PPSDM MIGAS

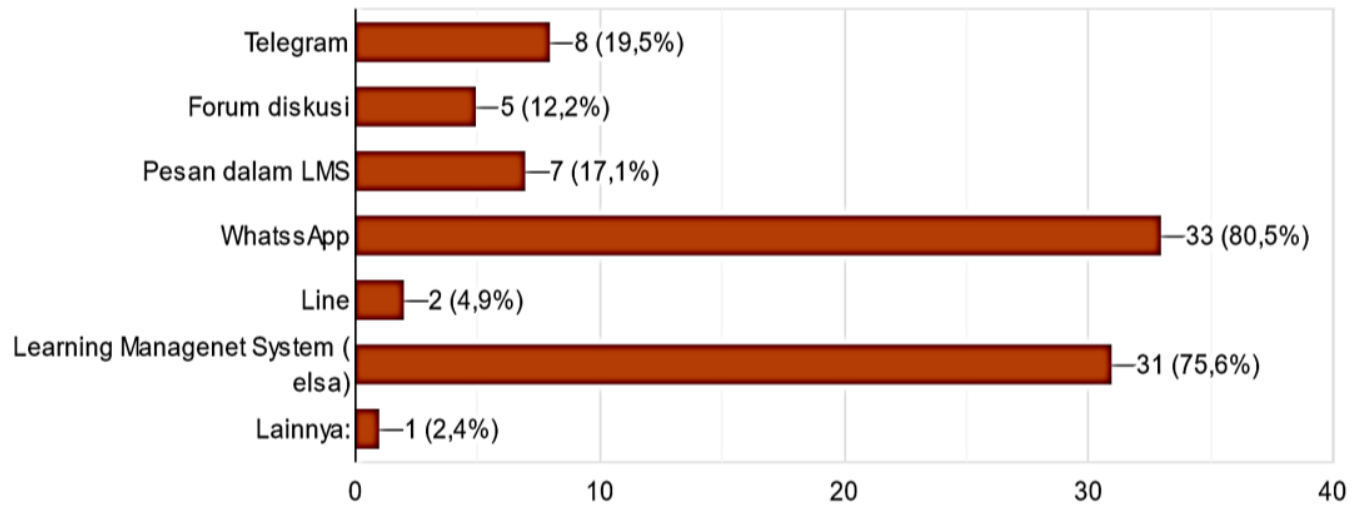

Gambar 9 Ragam aktivitas dan tool SINKRON yang digunakan dalam sistem pembelajaran daring di PPSDM MIGAS

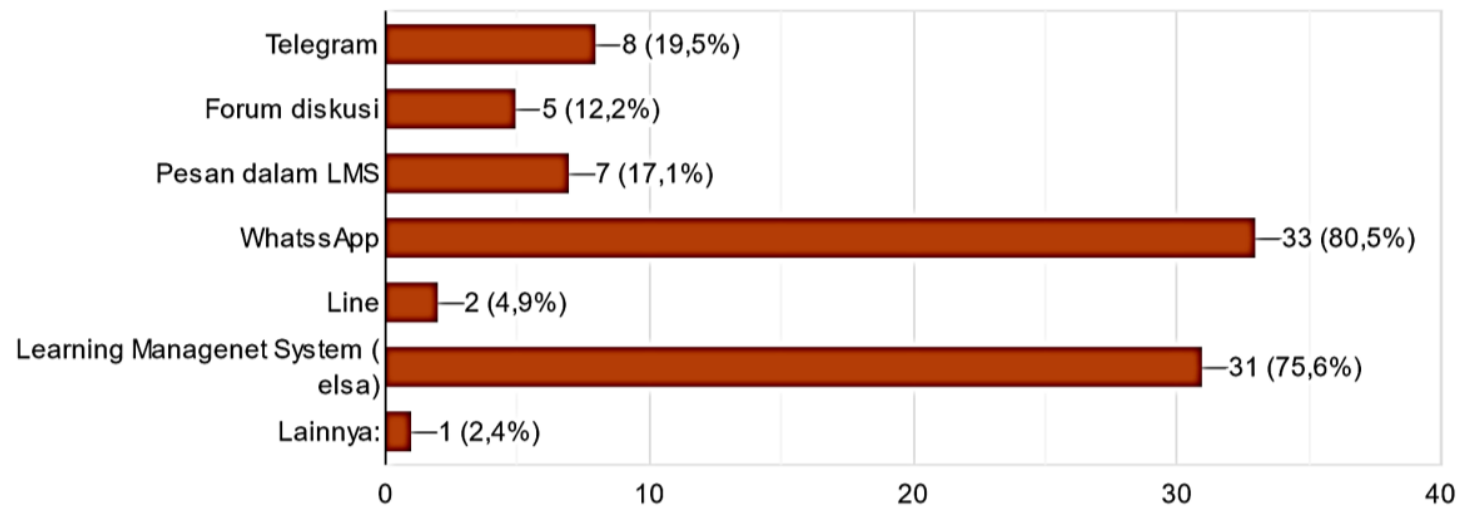

Gambar 10 Ragam aktivitas dan tool ASINKRON yang digunakan dalam sistem pembelajaran daring di PPSDM MIGAS 


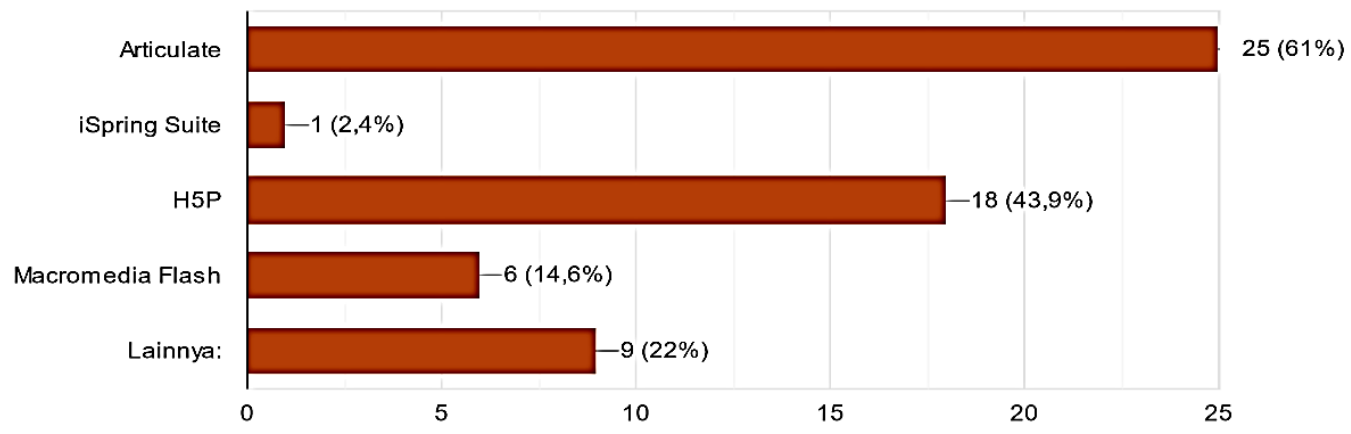

Gambar 11 Aplikasi dan tool yang digunakan untuk pengembangan objek ajar pembelajaran daring di PPSDM MIGAS

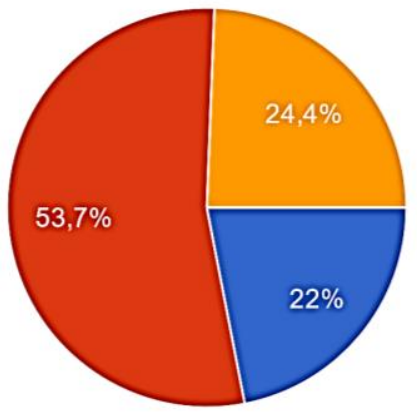

Di bawah 10 Mbps

10-20 Mbps

20 Mbps - 100 Mbps

- Di atas $1 \mathrm{Gbps}$

Gambar 12 Besar bandwidth wifi yang diterima anda di lingkungan PPSDM MIGAS

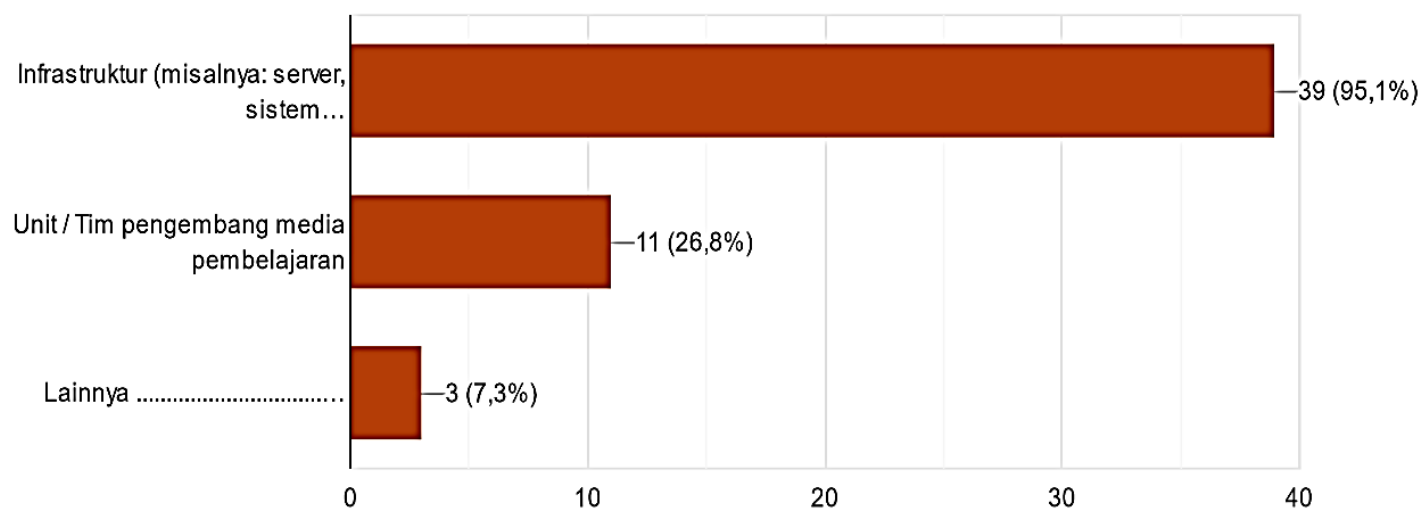

Gambar 13 Sistem pendukung yang tersedia di PPSDM MIGAS 


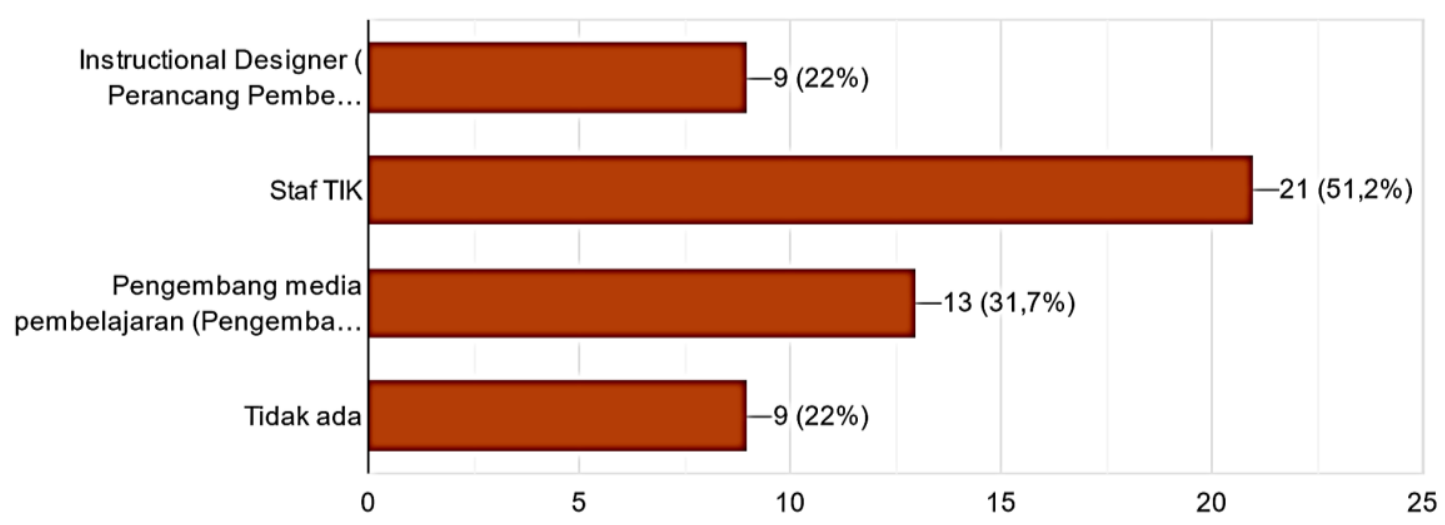

Gambar 14 SDM pendukung pembelajaran daring di PPSDM MIGAS

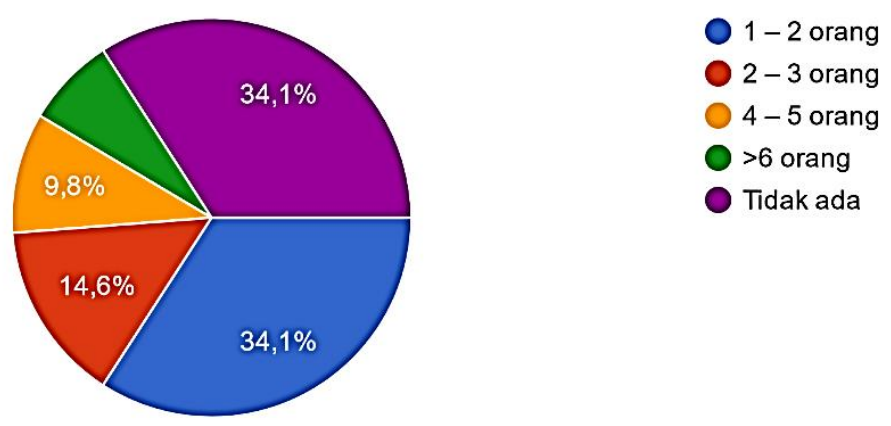

Gambar 15 Jumlah SDM yang terlibat dalam Instructional designer (Perancang Pembelajaran)
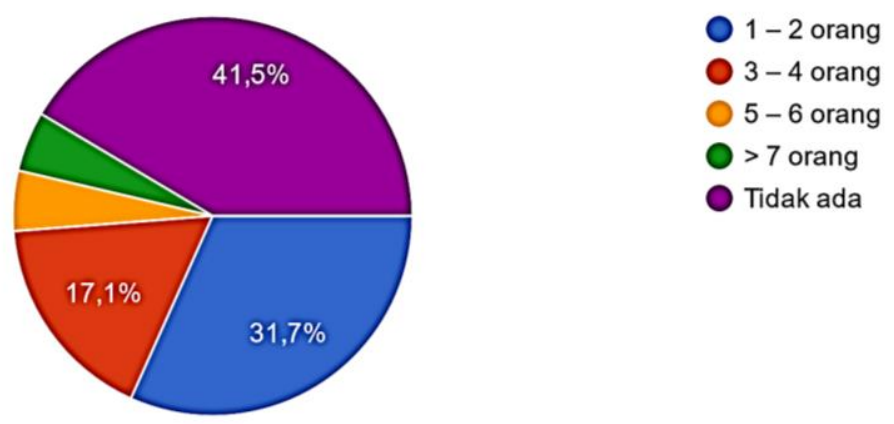

Gambar 16 Jumlah SDM yang terlibat pengembang media pembelajaran (perancang, pembuatan video pembelajaran dll) 


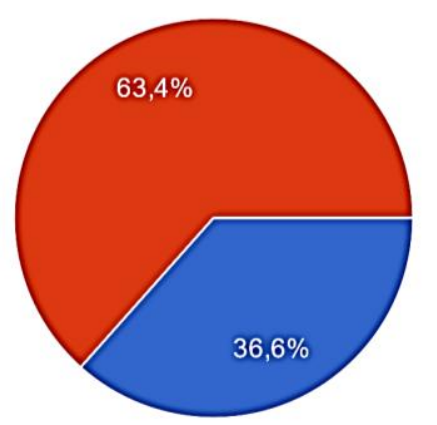

\section{Ya \\ Tidak}

Gambar 17 PPSDM MIGAS memiliki unit penanggung jawab mutu pembelajaran secara daring

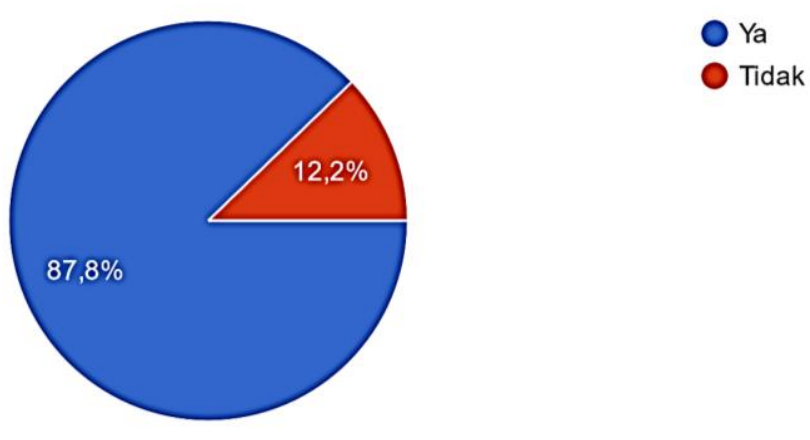

Gambar 18 PPSDM MIGAS memberikan pelatihan bagi staf yang terlibat dalam program pembelajaran daring

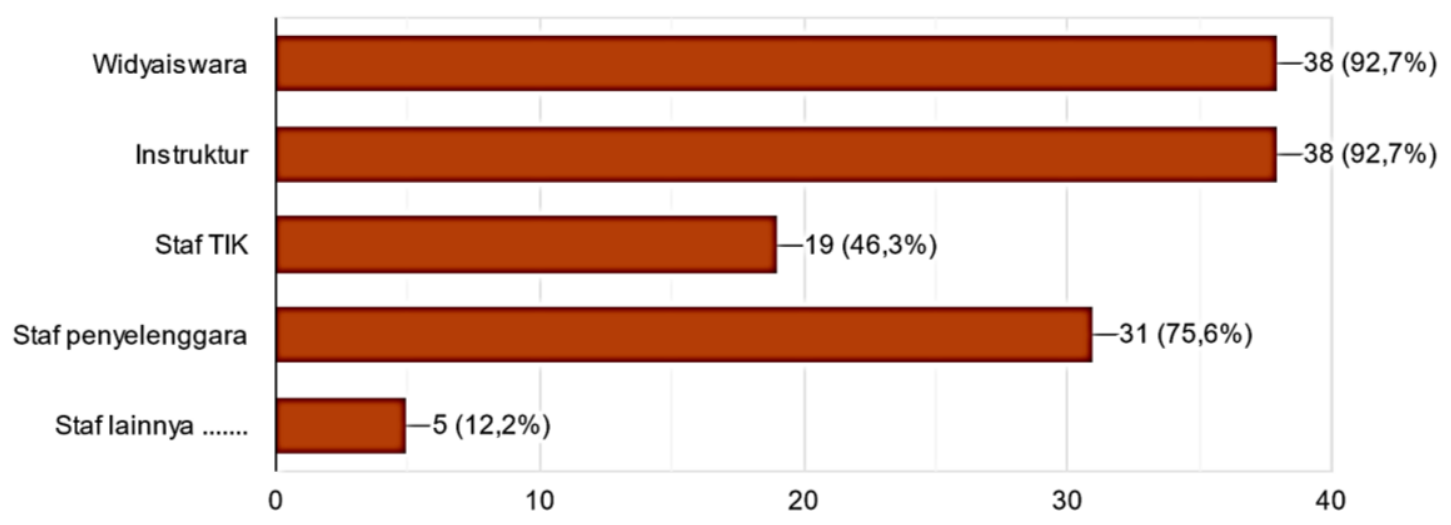

Gambar 19 Peserta pelatihan dari pegawai PPSDM MIGAS yang sudah mengikuti Pembelajaran daring 


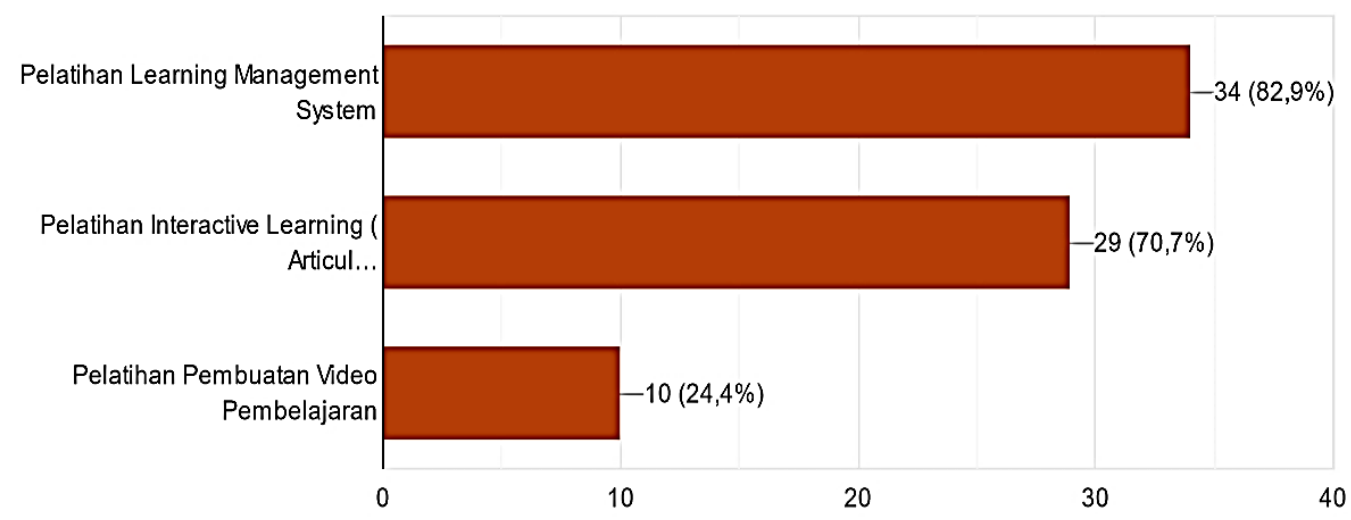

Gambar 20 Materi pelatihan yang sudah diberikan oleh instansi Anda
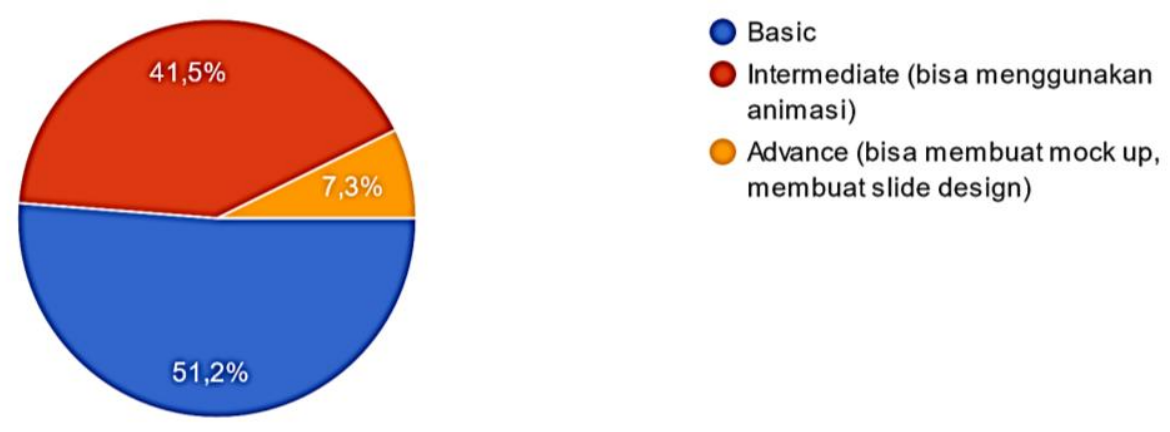
animasi)

Advance (bisa membuat mock up, membuat slide design)

Gambar 21 Kemampuan bisa menggunakan power point

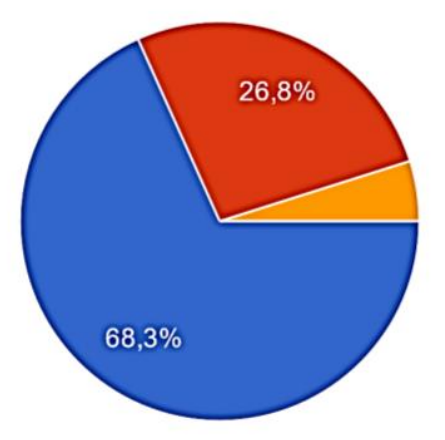

Basic

Intermediate (bisa menggunakan link antar halaman)

- Advance (bisa membuat berbagai menu membuat slide design)

Gambar 22 Kemampuan menggunakan software Interaktif Learning 

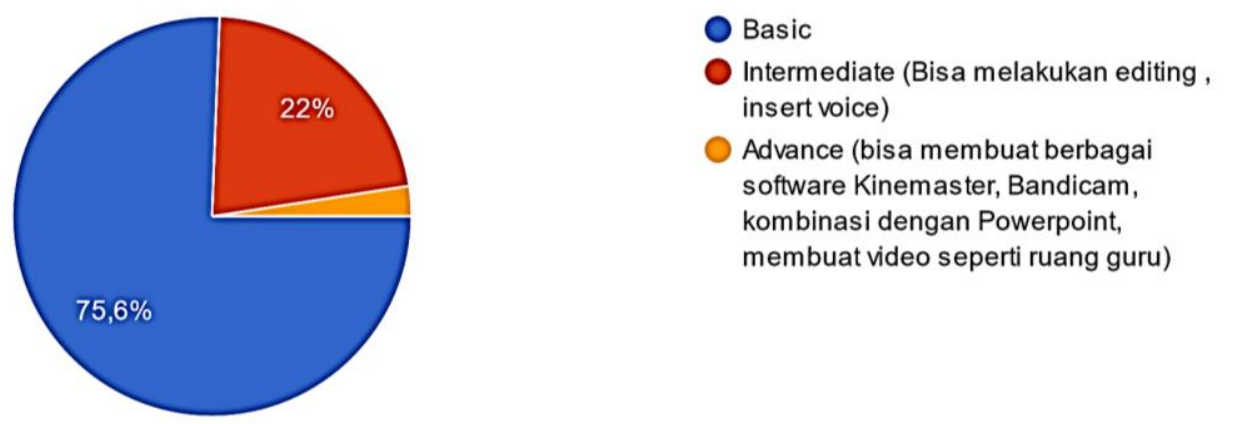

Gambar 23 Kemampuan menggunakan software video pembelajaran?

Dari hasil penelitian yang dilakukan adalah dengan survey melalui angket dengan google form yang disebar kepada stake holder penyelengara pelatihan dan pengajar (Widyaiswara dan instruktur). Dan studi ini adalah studi deskripsi sehingga tidak adanalisis kuantitatif hanya menggambarkan prosentase hasil survey yang ada. Ada beberapa pertanyaan yang diberikan kepada 50 responden diperoleh data bahwa 97,6\% menyatakan PPSDM MIGAS melaksanakan pembelajaran daring (Gambar 4), 95,1\% menyatakan pembelajaran dari adalah kombinasi Video conference dan LMS (Gambar 1), 82,9\% pengajar mampu menyelenggarakan pembelajaran daring, 95,1\% lebih senang dengan zoom daripada platform lainnya, 80,5\% lebih senang Whatsapp grup sebagai asinkron dalam pembelajaran online ada di Gambar 10, Dalam penggunaan internet sebagai pendukung pembelajaran daring $22 \%$ menerima bandwith di bawah $10 \mathrm{Mbps}$ (Gambar 12). 90,2\% Ragam objek ajar apa saja yang digunakan dalam pembelajaran daring di PPSDM MIGAS menggunaka visual ada di Gambar 7. Seperti yang sudah diteliti oleh peneliti sebelumnya Yeni Rimadeni, SKM, M.Si, pada tulisannya di halaman 47 - 53, Pemanfaatan E-Learning Untuk Pembelajaran Daring Di Masa Pandemi Covid-19 (Akhlis Munazilin, Mushidah, Lili Tansliova et all, 2020).

Namun sayangnya PPSDM MIGAS belum mempunyai Unit Penjaminan Mutu dalam Pembelajaran daring ini seperti pada Gambar 17, SDM yang terlibat dalam Instructional designer (Perancang Pembelajaran) Gambar 15, SDM yang terlibat pengembang media pembelajaran (perancang, pembuatan video pembelajaran dll) juga belum ada sesuai Gambar 16, dan juga kemampuan pengajar menggunakan Power Point bisa dilihat pada Gambar 21, pembelajaran interaktif dan penggunaan software video pembelajaran sebagai media pembelajaran masih dalam taraf Basic Gambar 22, sehingga untuk memperoleh hasil yang maskimal perlu ada pelatihan bagi insan stakeholder yang terlibat dalam pembelajaran daring untuk pengembangan SDM di dalam materi Power Point, Interactive Learning Content, dan pembuatan Video pembelajaran.sebagaimana di Gambar 23.

Terkait dengan Bandwith, akan lebih baik stakeholder pengajar dan penyelenggara diklat diberi tambahan paket data, yang terkoneksi dengan jaringan $4 \mathrm{G}+$ telekomunikasi selular yang ada, karena apabila mengandalkan jaringan kantor akan berpengaruh kecepatannya, karena semua system di perkantoran sudah menggunakan web based dan digunakan untuk pertemuan atau rapat online dengan video conference. Hal ini juga sama dengan yang sudah disampaikan 
oleh peneliti terdahulu Agus Nurofik, S.Kom., MM. pada tulisannya Hambatan Pembelajaran Di Masa Pandemi pada halaman 68 (Akhlis Munazilin, Mushidah, Lili Tansliova et all, 2020)

\section{KESIMPULAN}

Keberadaan dan implementasi pembelajaran daring PPSDM MIGAS sudah melaksanakan pembelajaran secara daring, sejak diberlakukan Working From Home (WFH), dan sudah menggunakan Learning Management System dengan system Moodle, Proses Pembelajaran yang sudah dilaksanakan menggunakan blended learning kombinasi antara video conference dan dukungan Learning Management Sytem sebagai asynchronous dan jalur komunikasi WA grup dan Telegram.

Peta proses, infrastruktur pembelajaran daring Infrastuktur mempunyai kendala Bandwith yang lemah juga merupakan hambatan dalam pembelajaran daring ini, oleh karena itu harus disiasati dengan strategi penyampaian video pembelajaran yang bisa diikuti semua peserta pelatihan, kemudian perlu dibentuk unit penjamin mutu agar standar pada seluruh kegiatan pembelajaran di PPSDM MIGAS.

Sebagai saran perlu dibentuk Unit Penjaminan Mutu dan Standarisasi dalam media pembelajaran visual (bahan tayang, Video pembelajaran dan Interactive learning Content) dan perlu diberikan subsidi pulsa kepada Widyaiswara, Instruktur dan Tenaga Administrasi Diklat seperti yang diberikan Kemendikbud bagi tenaga Dosen dan Tenaga Kependidikan, minimal $15-20$ GB per bulan.

\section{DAFTAR PUSTAKA}

Akhlis Munazilin, Mushidah, Lili Tansliova et all. (2020). PROSES KEGIATAN BELAJAR MENGAJAR (KBM) PADA MASA PANDEMI COVID-19 DI PERGURUAN TINGGI INDONESI (Kumpulan Esai). Situbondo: Bashish Publishing .

Ali Sadikin, A. H. (2020). Pembelajaran Daring di Tengah Wabah Covid-19. BIODIK: Jurnal Ilmiah Pendidikan Biologi Universitas Jambi, 214 - 224.

ESDM, S. J. (2020). Surat Edaran. Jakarta: Setjen ESDM.

Hilna Putria . (2020). Analisis Proses Pembelajaran Dalam Jaringan (DARING) Masa Pandemi COVID-19 pada Guru Sekolah Dasar. JURNAL BASICEDU Research \& Learning in Elementary Education , 861 - 872.

Novy Trisnani, M. (2019). Modul Teknik Sampling dan Survey. Wates Kulon Progo: IKIP PGRI Wates.

Prof. Dr. F. Ridwan Sanjaya, MS.IEC . (2020). 21 Refleksi Pembelajaran Daring di Masa Darurat. Semarang: Universitas Katolik Soegijapranata.

Waryanto, N. H. (2006). On-line Learning Sebagai Salah Satu Inovasi Pembelajaran. Pythagoras, 2(1), 10-23. 